\title{
Appendicitis, fibre intake and bowel behaviour in ethnic groups in South Africa
}

\author{
Alexander R. P. WAlker \\ D.Sc. \\ B. FAITH WALKER \\ BARBARA D. RICHARDSON \\ M.Sc. \\ ATHOLIE WOOLFORD \\ B.A. \\ South African Medical Research Council Human Biochemistry Research Unit, \\ South African Institute for Medical Research, Johannesburg, South Africa
}

\begin{abstract}
Summary
Information on appendicectomy-prevalence was secured on 15,317 16-20-year-old South African pupils and students-Negroes, Coloureds (Eurafricans), Indians and Caucasians. Data were also obtained on crude fibre-intake, frequency of defaecation, and transit-time of digesta.
\end{abstract}

Among students, 18-20 years, appendicectomy was very uncommon in rural Negroes $(0.5 \%)$ and periurban Negroes $(0.9 \%)$, slightly more common in urban Negroes $(1.4 \%)$, but very common in Caucasians $(16.5 \%)$; prevalences in Coloured and Indian groups were low (1.7 and 2.9\%). Rural Negroes had a far larger fibre-intake, greater frequency of defaecation, and much shorter transit-time; yet, in the four ethnic groups in urban areas, despite wide differences in appendicectomy-prevalence, data on these variables were similar. Differences in other aspects of the bowel milieu intérieur must therefore be sought.

Corresponding studies were made on 1325 Caucasian pupils in Homes; their diet is less sophisticated (in respect of fibre, sugar and fat-intakes) than that of the general population. Pupils had slightly greater defaecation-frequency, lesser transit-time, and an appendicectomy-incidence only $23 \%$ of that of an appropriate control-group.

The conclusion is reached that the causes of appendicitis are wholly environmental.

\section{Introduction}

In primitive and under-privileged populations in developing countries, appendicitis is rare, yet it rises in prevalence with improvement in socio-economic circumstances (Gelfand, 1956; Trowell, 1960; Boroda, 1961; Bremner, 1964; Janssens \& de Muynck, 1966; Burkitt, 1969, 1971). A century or

Correspondence: Dr A. R. P. Walker, South African Institute for Medical Research, P.O. Box 1038, Johannesburg, South Africa. less ago, the disease in western populations was infrequent (Mackenzie, 1878; Brunton, 1896; MacEwen, 1904; Murray, 1914; Mayo, 1924); at present it is the foremost cause of abdominal emergencies (Wright, 1963; Janssens \& de Muynck, 1966; Ashley, 1967). Rendle Short $(1920,1946)$ maintained that the increase correlated with changes in diet, principally the progressive decrease in the consumption of crude fibre; the level of intake of this component regulates bowel motility and the amount of faeces voided per diem (Rendle Short, 1920, 1946; Hoppert \& Clark, 1945; McCance \& Widdowson, 1946; Walker, 1947, 1961, 1970; Janssens \& de Muynck, 1966; Burkitt, 1971). Cleave, Campbell \& Painter (1969) attach chief blame to an increased consumption of refined carbohydrate foods, particularly sugar. Burkitt $(1969,1971)$, and associate workers (Burkitt, Painter \& Walker, 1972), believe changes in fibre intake to be strongly implicated; they regard appendicitis as the earliest of a series of diseases-appendicitis, diverticular disease, and cancer of the colon-which become increasingly common with sophistication of diet and manner of life.

In South Africa, there is a juxtaposition of Negro, Coloured (Eurafrican), Indian and Caucasian populations, in various stages of westernization. An endeavour has therefore been made, firstly, to throw more light on the extent of the relationship between diet, especially fibre-intake, bowel behaviour, and the prevalence of appendicitis. Secondly, it was desired to determine whether among Caucasians there is evidence that reversion to a less sophisticated diet is followed by a fall in the occurrence of the disease.

Materials and methods

Subjects

Investigations were made on two types of population. 
Group I included school pupils and University or College students; these are populations which are readily accessible for investigation. They are especially apposite for study since peak prevalence of appendicectomy occurs at late adolescence, 15-19 years (Reid, Poer \& Merrel, 1936; Young \& Russell, 1939; Lee, 1962; Wright, 1963; Ashley, 1967; Howorth, 1969). Subjects, males and females, in the four ethnic groups included (i) 10,101 senior pupils at schools in Johannesburg, Durban, and a number of country districts; and (ii) 5216 students attending Universities or Colleges in Johannesburg, Pretoria, Potchefstroom, Grahamstown and Durban. School pupils comprised all those aged 16-18 on school registers. The student groups, of 18-20 years, were all those either attending specific courses or dwelling in halls of residence.

Group II included pupils in Homes (admitted for indigence or adverse family circumstances), who were accustomed to a diet less sophisticated than is consumed by pupils in the general population. There were three Homes, one large and two small. Subjects included 650 boys, and 675 girls, aged 6-16, whose health records were available for 10 years. As comparisons, data were obtained from two State schools on 660 boys and 688 girls, of the same age range, but for a 2-year period only.

\section{Methods}

Appendicitis. As an index of frequency of appendicitis, prevalence of appendicectomy was used. It is understood, of course, that the rate for unequivocal appendicitis is lower than the rate for appendicectomy, due to the proportion of organs removed for preventive or even prophylactic surgery. The true value may be $75-98 \%$ of the appendicectomy rate, at least for Caucasians (Reid et al., 1936; Young \& Russell, 1939; Howorth, 1969). Prevalences of appendicectomy in the different ethnic, sex and age groups were obtained using a questionnaire.

Diet. General information (Walker, 1966; Walker, Holdsworth \& Walker, 1971) is as follows.

Group I. Caucasians. Their diet is substantially the same as that consumed in western countries. In the adult population, total fat supplies about $30-40 \%$ of calories. Sugar-intake averages about $90 \mathrm{~g}$ per diem among those mainly in business or profession, and $130 \mathrm{~g}$ per diem chiefly among manual workers. Fibre-intake is low.

Coloureds. Their diet is similar to that consumed by Caucasians in lower socio-economic levels. Cereal-food-intake is higher than that of average Caucasians, fat-intake is lower, but sugar-intake is much the same (about $90 \mathrm{~g}$ per diem).

Indians. Moslems, as a rule, are non-vegetarians, apart from abstaining from pork. Some Hindus are vegetarian, others non-vegetarian, apart from not eating beef. Carbohydrate foods are rice, wheat, potatoes, and sugar. Fat is derived from ghee and vegetable oils. For Hindu vegetarians, chief sources of protein are milk, legumes and cereals; and for non-vegetarians, mutton, chicken, eggs, milk, legumes and cereals. In Transvaal Indians, fat supplies about $30-40 \%$ of calories. Sugar consumption averages about $80 \mathrm{~g}$ per diem. Fibre-intake is low.

Negroes. Among country Negroes, the traditional diet is largely followed. Broadly, maize is still the chief staple, supplemented by 'kaffir corn' (Sorghum vulgare), millet and wheat products. Additional foods are dried peas, beans, groundnuts, pumpkin, 'kaffir melon', and various other vegetables, fruit and wild greens. Meat is consumed 2-3 times/week. In towns, the majority of Negroes buy their own food and consume a partially westernized diet. Meat is eaten usually every day. Total fat supplies about $15-20 \%$ of calories in country areas, and $20-35 \%$ in towns. Sugar consumption is very variable, but roughly average consumptions are $30-75 \mathrm{~g}$ per diem in country, and about $55-85 \mathrm{~g}$ in towns. Fibre-intake is high in the country, but much lower in town areas.

Group II. Homes diet. Breakfast; porridge (milk, sugar), brown bread plus a half and half butter/ margarine mixture, peanut butter, or jam, plus coffee. Lunch (main meal); meat or fish, potatoes, two vegetables, stamped mealies or mealie rice (maize), salads, fruit, occasionally pudding. Supper; bread, butter/margarine mixture, soup, or cheese, or egg bread, or macaroni, or milk pudding: and occasionally raisins and dried fruit. One glass of milk daily. Household sugar allowance, $60 \mathrm{~g}$ per diem. The consumption of cakes, pastries, sweets, soft drinks, ice cream, etc., is much lower than that of pupils in the general population.

Crude fibre-intake. Representative data on South African foods were available from earlier studies: values were obtained by the orthodox method of acid and alkali digestion (Cox, 1946). In Group I, representative fibre-intakes were calculated from 3 day diet recall periods obtained from fifty persons (twenty-five males, twenty-five females) in each group of Negroes (rural, peri-urban, and urban), and in Coloured, Indian and Caucasian groups of students in urban areas. In Group II, the fibre-intake of pupils in the Homes was calculated from dietary information supplied by the resident dietician.

Frequency of defaecation and transit time of digesta. Group I: $500 \mathrm{mg}$ carmine in two gelatine capsules were ingested at breakfast by 100 males and 100 females in the six sub-groups mentioned. Each person entered on a form the time and colour of motions voided over a 7 day period. The time elapsing until the first appearance of carmine colour in the faeces was reckoned as transit time. Group II: 
data were obtained from twenty-five boys and twenty-five girls, aged 14-16, from the Homes.

Results are summarized in Tables 1-4.

\section{Appendicitis-prevalence}

Group I. School pupil and student groups. As expected, data on the student groups were slightly higher than the data on the school pupils. In the student groups, the disease was rare in rural Negroes $(0.5 \%)$, very infrequent in peri-urban Negroes $(0.9 \%)$, and slightly more common in urban Negroes $(1.4 \%)$. Rates in Coloured and Indian groups $(1.7 \%$ and $2.9 \%$ ) were somewhat higher than that for urban Negroes, but were far lower than that for Caucasians $(16.5 \%)$.
The obvious immediate question is, how reliable are these data? At the one extreme, in rural Negroes, the rarity of the disease is vouched for by the experience at many mission hospitals (Burkitt, 1971); most of them in South Africa are ably staffed and well equipped. But probably the best confirmatory evidence is afforded from Negro labourers recruited from rural areas in Southern Africa, and employed on the gold-mines. The age-range for the great majority is 19-24. They are fed on an adequate diet which includes large amounts of high-extraction cereal products, legumes, and vegetables. In one mining group the labour force is about 100,000 . Firstly, taking into account the war-time appendicectomy incidence in the U.S.A. Navy (Editorial,

TABLE 1. Fibre intake, frequency of defaecation, and transit time of school pupils and students (Group I)

\begin{tabular}{|c|c|c|c|c|c|c|c|}
\hline & \multicolumn{3}{|c|}{ Bantu } & \multirow[t]{2}{*}{ Coloureds } & \multirow[t]{2}{*}{ Indians } & \multicolumn{2}{|c|}{ Caucasians } \\
\hline & Rural & $\begin{array}{l}\text { Peri- } \\
\text { urban }\end{array}$ & Urban & & & $\begin{array}{l}\text { Without } \\
\text { appendicectomy }\end{array}$ & $\begin{array}{c}\text { With } \\
\text { appendicectomy }\end{array}$ \\
\hline $\begin{array}{l}\text { Average crude fibre intake } \\
\text { (g/day) } \\
\text { Mean frequency of defaecation }\end{array}$ & $22 \cdot 0$ & $12 \cdot 5$ & $6 \cdot 8$ & $5 \cdot 4$ & $4 \cdot 0$ & $4 \cdot 6$ & $4 \cdot 0$ \\
\hline $\begin{array}{l}\text { (motions/week) } \\
\text { Mean transit time (hr) }\end{array}$ & $\begin{array}{l}16 \cdot 0 \\
14 \cdot 2\end{array}$ & $\begin{array}{l}13 \cdot 0 \\
18 \cdot 1\end{array}$ & $\begin{array}{r}8 \cdot 1 \\
22 \cdot 5\end{array}$ & $\begin{array}{r}6 \cdot 8 \\
28 \cdot 8\end{array}$ & $\begin{array}{r}6 \cdot 9 \\
27 \cdot 3\end{array}$ & $\begin{array}{c}7 \cdot 1 \\
29 \cdot 1\end{array}$ & $\begin{array}{c}6 \cdot 8 \\
30 \cdot 4\end{array}$ \\
\hline
\end{tabular}

TABLE 2. Prevalence of appendicectomy in South African ethnic groups of school pupils and students (Group I)

\begin{tabular}{|c|c|c|c|c|c|c|}
\hline & \multicolumn{3}{|c|}{ Bantu } & \multirow[t]{2}{*}{ Coloureds } & \multirow[t]{2}{*}{ Indians } & \multirow[t]{2}{*}{ Caucasians } \\
\hline & Rural & $\begin{array}{l}\text { Peri- } \\
\text { urban }\end{array}$ & Urban & & & \\
\hline $\begin{array}{l}\text { School pupils (16-18) } \\
\text { High-school or University } \\
\text { students }(18-20)\end{array}$ & $\begin{array}{c}7 / 2226 \\
=0.3 \% \\
3 / 590 \\
=0.5 \%\end{array}$ & $\begin{array}{l}4 / 1280 \\
=0.3 \% \\
5 / 541 \\
=0.9 \%\end{array}$ & $\begin{array}{l}10 / 1400 \\
=0.7 \% \\
8 / 571 \\
=1.4 \%\end{array}$ & $\begin{array}{l}8 / 1306 \\
=0.6 \% \\
12 / 720 \\
=1.7 \%\end{array}$ & $\begin{array}{l}20 / 1980 \\
=1.0 \% \\
20 / 699 \\
=2.9 \%\end{array}$ & $\begin{array}{l}191 / 1909 \\
=10 \cdot 0 \% \\
377 / 2295 \\
=16.5 \%\end{array}$ \\
\hline
\end{tabular}

TABLE 3. Fibre intake, frequency of defaecation, and transit time in the Home pupils (Group II)

\begin{tabular}{lc}
\hline & Home pupils \\
\hline $\begin{array}{l}\text { Average crude fibre } \\
\text { intake (g/day) }\end{array}$ & $6 \cdot 9$ \\
$\begin{array}{l}\text { Mean frequency of } \\
\text { defaecation } \\
\text { (motions/week) }\end{array}$ & $8 \cdot 0$ \\
$\begin{array}{l}\text { Mean transit time } \\
\text { (hr) }\end{array}$ & $26 \cdot 3$ \\
\hline
\end{tabular}

TABLE 4. Incidence of appendicectomy in the Home pupils (Group II)

\begin{tabular}{|c|c|c|}
\hline Population & $\begin{array}{l}\text { Appendicectomy } \\
\text { frequency }\end{array}$ & $\begin{array}{l}\text { Appendicectomies/ } \\
1000 \text { persons/year }\end{array}$ \\
\hline Homes & $\begin{array}{l}1325 \text { pupils: } 10 \text { years; } \\
650 \text { boys, } 675 \text { girls, } \\
24 \text { appendicectomies } \\
\text { (10 boys; } 14 \text { girls) }\end{array}$ & $1 \cdot 8$ \\
\hline $\begin{array}{l}\text { Matched } \\
\text { school } \\
\text { group }\end{array}$ & $\begin{array}{l}1348 \text { pupils: } 2 \text { years; } \\
660 \text { boys, } 688 \text { girls, } \\
21 \text { appendicectomies } \\
\text { (11 boys; } 10 \text { girls) }\end{array}$ & $7 \cdot 8$ \\
\hline $\begin{array}{l}\text { Bristol* } \\
\text { Children's } \\
\text { Home }\end{array}$ & $\begin{array}{l}950 \text { pupils: } 5 \text { years; } \\
350 \text { boys, } 600 \text { girls, } \\
4 \text { appendicectomies } \\
\text { (all girls) }\end{array}$ & 0.8 \\
\hline $\begin{array}{c}\text { Bristol* } \\
\text { Public } \\
\text { School }\end{array}$ & $\begin{array}{l}500 \text { boys: } 5 \text { years, } \\
19 \text { appendicectomies }\end{array}$ & $7 \cdot 6$ \\
\hline
\end{tabular}

* Bristol data (Rendle Short, 1946) 
1949), and secondly using the probability data reported from New Zealand (Ludbrook \& Spears, 1965), then roughly 850 appendicectomies would be expected annually from a Caucasian group of the same size as the Negro mineworkers. Yet among the latter in 1970 there were only twenty-two operations (Annual Report, 1970).

At the other extreme, among the Caucasians, the relative constancy of the data obtained from different parts is noteworthy. In Johannesburg and Pretoria, large cities with medical schools, mean appendicectomy rates for students were 18.2 and $13.0 \%$, respectively. Yet at Potchefstroom and Grahamstown, small country towns, rates were much the same, namely, 19.4 and $16.7 \%$, respectively. Universities in the latter towns include a large moiety of students brought up in country areas. A further important point concerns the closeness of our combined data to those reported elsewhere. Using data on the age-distribution of appendicectomy given by Wright (1963) and Ashley (1967), calculations indicate that prevalence of the operation per total population of South African Caucasians is about $17 \%$, a proportion which closely resembles that for England (Ashley, 1967), about 14\%, and for New Zealand (Ludbrook \& Spears, 1965), about 16\%. These two items of information suggest that the standard of judgment as to whether or not to perform appendicectomy is roughly the same in different parts.

From the foregoing we believe our appendicectomy data to be reliable.

Appendicectomy was slightly commoner in females than in males, as noted by Ashley (1967), although Ludbrook \& Spears (1965) in New Zealand reported the converse. For total Caucasians our figures were, males $15.1 \%$, females $18.0 \%$. Prevalence increased with age, in the groups studied, as found by others (Reid et al., 1936; Young \& Russell, 1939; Erasmus, 1939; Lee, 1962; Wright, 1963; Ludbrook \& Spears, 1965; Ashley, 1967; Howorth, 1969). Evidence suggests that in urban Negroes, prevalence of appendicectomy has doubled since 1939 (Erasmus, 1939).

Group II. Pupils in Homes. The incidence of appendicectomy among pupils in the Homes was only $23 \%$ of the incidence in the age and sex matched school group of non-institution children. There are, of course, limitations to the accuracy of these comparisons. However, our findings are supported by three types of evidence.

(i) Results are closely similar to those obtained in a comparable study described by Rendle Short (1946). From personal experience he reported that in Bristol in a public school of 500 boys who were liberally fed, there were nineteen cases of appendicitis in a 5 year period. In contrast, in a Children's Home of 950 inmates ( 350 boys and 600 girls) where the diet was simpler and coarser, there were only four cases (all girls) in the same period; this is roughly a tenth of the incidence in the public school. Both groups received the same level of medical attention.

(ii) Among people in places of confinement where the diet is much less rich than that of the general population, appendicitis is much less common. Briscoe in 1912 reported appendicitis to be very rare in mental hospitals and similar institutions in England and Wales; only seventy-five deaths from the disease occurred between 1902 and 1911. In Portland prison, Murray (1914) reported that only one death from the disease occurred during the previous 10-year period. In a South African prison which accommodated 500 Caucasian prisoners, there were only five cases of appendicitis in the previous 20 years (Swanepoel, 1947).

(iii) A third type of evidence citable in support concerns the situation in the last war in certain countries where the diet became one of high residue; there were reduced intakes of fat and sugar, and increased intakes of higher extraction bread and of vegetables. In Switzerland (Fleisch, 1946) and the Channel Islands (Banks \& Magee, 1945, evidence indicated that the incidence of appendicitis fell.

\section{Fibre-intake}

Group I. School pupils and students. There was a large fall in intake from rural Negroes to Caucasians. Our data on rural and urban Negroes, and on Caucasians, agree with values reported by others (Lubbe, 1971; Hardinge et al., 1958). However, differences in mean intake between urban Negroes, Coloureds, Indians and Caucasians were not large. Fibre-intake among urban Negroes is afforded chiefly by cereal products, in contrast to the three other groups among whom intake is derived from a mixture of foods. In Caucasians, there did not appear to be a difference between the current fibre-intake of those with and without appendicectomy.

Group II. Pupils in the Homes. The fibre-intake of pupils in the Homes was higher than that of pupils in the general population.

\section{Defaecation-frequency}

Group I. School pupils and students. There was a decrease in defaecation-frequency from rural Negroes 16.0 (motions per week), to Caucasians, 7.1. The latter figure is slightly higher than figures reported for comparable groups overseas, namely, 6.3 and 6.8 (Hardy, 1945; Connell et al., 1966). Frequency was slightly greater in males than in females, as noted by others (Hardy, 1945; Connell et al., 1966); among Caucasians, figures were $7 \cdot 3$ and 6.8 for the two sexes. Frequency in urban Negroes, 8.1, was close to that noted locally by Bremner (1964), i.e. 
7·8. Frequency differed little between urban Indians, Coloureds, and Caucasians. Defaecation did not appear to differ in frequency in Caucasians with and without appendicectomy.

Group II. Pupils in the Homes. The frequency of defaecation, $8 \cdot 0$, was slightly higher, compared with the general Caucasian population.

\section{Transit-time}

Group I. School pupils and students. There was a progressive increase in transit-time among Negroes from rural to urban areas, $14.0 \mathrm{hr}$ compared with $22.5 \mathrm{hr}$. For Caucasians, the mean, $29.1 \mathrm{hr}$, was virtually identical to that given for English subjects by Hinton, Lennard-Jones \& Young (1969), 29.6 hr. Means for Caucasian, Coloured and Indian groups, were closely similar. Among Caucasians who had appendicectomy, transit time was only slightly longer, $30.4 \mathrm{hr}$. For comparison, transit times in Rhodesian Negroes have been reported as follows: mineworkers, $10.8 \mathrm{hr}$; villagers, $13.8 \mathrm{hr}$; schoolchildren, $17 \cdot 2 \mathrm{hr}$ (these three groups were consuming their traditional diet); teacher trainees, $20.6 \mathrm{hr}$, (on a mixed diet); medical students, $28.4 \mathrm{hr}$ (on a refined diet) (Holmgren \& Mynors, 1972).

Group II. Pupils in the Homes. Mean transit-time, $26 \cdot 3 \mathrm{hr}$, was slightly less compared with the general population.

\section{Discussion}

Our findings, together with observations reported by others, strongly support the view that the causative factor or factors of appendicitis are wholly environmental. It is considered that the opinion that dismisses the influence of 'geography, diet and, culture' as 'mythical' (current comment, 1939), is untenable.

Among rural Negroes, appendicitis was rare in a context which included a high fibre-intake, a high defaecation-frequency, and a short transit-time. This was expected. In urban areas, there were considerable differences in appendicectomy-rates in the four ethnic groups; yet, unexpectedly, correspondingly diverse differences in the three variables were not apparent. Nor were there correspondingly diverse differences in refined cereal or in sugar-intakes; as indicated previously, in urban Negro, Indian, Coloured and middle-class Caucasian adults, mean sugar-intakes were found to be roughly $70 \mathrm{~g}, 80 \mathrm{~g}$, $90 \mathrm{~g}$, and $90 \mathrm{~g}$ per diem (Walker, Holdsworth \& Walker, 1971). Moreover, thus far, studies have not revealed a significant difference between the mean intakes of sugar of Caucasian students with and without appendicectomy. It is believed, however, that similarities in defaecation-frequency and transittime do not necessarily imply similarities in bowel milieu interieur. We speculate that in these urban groups there are highly relevant differences, of dietary origin, in the bowel milieu interieur, principally in the chemical and bacteriological composition of faeces (Hill et al., 1971). Differences are known to prevail in other respects. For example, our urban Negro and Caucasian school-children had much the same frequency of defaecation and transit time; yet $90 \%$ of urban Negroes can readily produce a stool on request in a few minutes; in Caucasian pupils the figure is less than $10 \%$ (Walker \& Walker, 1969).

Our results on the different ethnic groups are of obvious epidemiological interest, particularly the contrasting prevalences of appendicectomy between Negroes and Caucasians. Yet it must be recognized that there are limits to the drawing of meaningful conclusions from these populations, since there are differences in many variables other than diet (Walker, 1964). We believe that research on the aetiology of appendicitis (and other diseases whose prevalences change with sophistication) is likely to be more rewarding when carried out within western populations, e.g. on groups who, voluntarily or involuntarily, have been subjected to long-term dietary changes; and on minority groups within homogeneous populations whose diet differs from the average (Walker, 1971). On this account we attach chief importance to the results of our studies on the inmates of the Homes. Young \& Russell (1939) stated that 'under existing conditions of modern life, it seems improbable that a sufficient change in dietary habits will be introduced to influence to an appreciable extent the incidence of appendicitis'. Our findings on the population mentioned indicate that the incidence of appendicitis in a western community can indeed be markedly reduced. The diet in the Homes, as described earlier, is one that could readily be consumed throughout life. In pattern, it is the diet of our ancestors a century or so ago. A point of major practical importance is that the greatly reduced proneness to appendicitis appears to be conferred soon after commencing consumption of the diet.

Although information is available on the contexts in which appendicitis is common, knowledge of the immediate or precipitating causes is absent. In 1902 Treves stated that 'mere constipation alone would not appear sufficient as the exciting cause'. Rendle Short (1946) considered that in the great majority of cases no readily identifiable cause is apparent. In 1950, Zachary Cope, referring to the aetiology of appendicitis, went as far as to say that present learning was little in advance of what Fitz taught in 1886.

It is conceivable that in a given population there is only a limited proportion who develop appendicitis, and that the disease occurs presumably only when the milieu interieur of the bowel, regulated 
principally by diet, is propitious. The existence of this sub-population susceptible to the disease was postulated by Ashley (1967) who considered the proportion to be about $12 \%$. There is no certainty, of course, that the proportion is the same for all populations.

Finally, it is reiterated that it is gratifying to learn that a diet not far removed from the everyday diet of western populations, i.e. that consumed in the Homes, is associated with a very low incidence of appendicitis. Yet this disease is not a major cause of morbidity or mortality. In the introduction the belief was expressed that appendicitis is the earliest of a series of diseases-appendicitis, diverticulitis, cancer of the colon-which become increasingly common with sophistication of diet and manner of life. Colonic cancer, next to lung cancer, is the most lethal of neoplastic diseases. It would be of immense public health importance if it could be shown that consumption of the Home type of diet, if sustained over the years, would be associated with an incidence of cancer of the colon far lower than the average. While not impossible, this would be extremely difficult to demonstrate.

\section{Acknowledgments}

We are very much indebted to Miss Munira Wadvalla for technical assistance. The work described was carried out with the assistance of a grant from the National Cancer Association of South Africa. Much of the information on fibre-intake was secured when determining sugar-intakes in the different groups; this aspect of the work was undertaken with assistance of grants from the South African Sugar Association, and the International Sugar Research Foundation.

\section{References}

Annual Report (1970) Medical Department, Gold Fields of South Africa Limited, Johannesburg.

Ashley, D.J.B. (1967) Observations on the epidemiology of appendicitis. Gut, 8, 533.

BanKS, A.L. \& MAGEe, H.E. (1945) Effects of enemy occupation on the state of health and nutrition in the Channel Islands. Monthly Bulletin of the Ministry of Health and the Public Health Laboratory Service, 4, 184.

BorodA, C. (1961) The incidence of acute appendicitis in African patients. East African Medical Journal, 38, 83.

Bremner, C.G. (1964) Ano-rectal disease in the South African Bantu. I. Bowel habit and physiology. South African Journal of Surgery, 2, 119.

BRISCOE, J.F. (1912) Appendicitis in institutions. Lancet, ii, 175.

BRUNTON, T.L. (1896) On constipation and diarrhoea. Lancet, i, 1483.

BURKIT,, D.P. (1969) Related disease-related cause? Lancet, ii, 1229.

BURKITT, D.P. (1971) The aetiology of appendicitis. British Journal of Surgery, 58, 695.

BURKITT, D.P., WALKeR, A.R.P. \& PAINTER, N.S. (1972) Effect of dietary fibre on stools and transit-times, and its role in the causation of disease. Lancet, ii, 1408.

Cleave, T.L., Campbell, G.D. \& Painter, N.S. (1969) Diabetes, Coronary Thrombosis and the Saccharine Diseases. Wright, Bristol.
Connell, A.M., Hilton, C., Irvine, G., Lennard-Jones, J.E. \& Misiewicz, J.J. (1966) Variation of bowel habit in two population samples. Proceedings of the Royal Society of Medicine, 59, 11.

COPE, V.Z. (1950) The acute appendix. British Medical Journal, 1, 1242.

Cox, H.E. (1946) The Chemical Analysis of Foods. Churchill, London.

Current Comment (1939) Genesis of appendicitis. Journal of the American Medical Association, 112, 2606.

EDItORIAL (1949) Mortality in appendicitis. United States Naval Medical Bulletin, 49, 1180.

ERASMUS, J.F.P. (1939) The incidence of appendicitis in the Bantu. South African Medical Journal, 13, 601.

Fitz, R.H. (1886) Perforating inflammation of the vermiform appendix, with special reference to its early diagnosis and treatment. American Journal of Medical Science, 92, 312.

FleisCH, A. (1946) Nutrition in Switzerland during the war. Schweizerische Medizinische Wochenschrift, 76, 889.

Gelfand, M. (1956) The Sick African, 3rd edn. Stewart, Cape Town.

Hardinge, M.G., Chambers, A.C., Crooks, H. \& Stare, F.J. (1958) Nutritional studies of vegetarians. III. Dietary levels of fiber. American Journal of Clinical Nutrition, 6, 523.

HARDY, T.L. (1945) Order and disorder in the large intestine. Lancet, i, 519, 553.

Hill, M.J., Crowther, J.S., Draser, B.S., Hawkesworth, G., Aries, V. \& Williams, R.E.O. (1971) Bacteria and aetiology of cancer of large bowel. Lancet, $\mathbf{i}, 95$.

Hinton, J.M., Lennard-Jones, J.E. \& Young, A.C. (1969) A new method for studying gut transit times using radioopaque markers. Gut, 10, 842 .

Holmgren, G.O.R.\& MYNORS, J.M. (1972) The effect of diet on bowel transit times. South African Medical Journal, 46, 918.

Hoppert, C.A. \& Clark, A.J. (1945) Digestibility and effect? on laxation of crude fiber and cellulose in certain common foods. Journal of the American Dietetic Association, 21, 157.

HoworTH, M.B. (1969) Acute appendicitis in a small community hospital. Southern Medical Journal, 62, 548.

JANSSENS, P.G. \& DE MUYNCK, A. (1966) Appendicular pathology in the African Negro. Tropical and Geographical Medicine, 18, 81.

LEE, J.A.H. (1962) The influence of sex and age on appendicitis in children and young adults. Gut, 3, 80 .

LubBe, A.M. (1971) Study of rural and urban Venda males: dietary evaluation. South African Medical Journal, 45, 1289.

LudbrooK, J. \& SPEARS, G.F.S. (1965) The risk of developing appendicitis. British Journal of Surgery, 52, 856.

McCance, R.A. \& Widdowson, E.M. (1946) An Experimental Study of Rationing, Special Report Series, Medical Research Council, No. 254. H.M.S.O., London.

MACEwEN, E.W (1904) The function of the caecum and appendix. British Medical Journal, 2, 873.

MaCKenzie, S. (1878) Two cases of perityphlitis with remarks. Lancet, ii, 402.

Mayo, C.H. (1924) The appendix in relation to, or as the cause of, other abdominal diseases. Journal of the American Medical Association, 83, 592.

MuRRAY, R.W. (1914) The geographical distribution of appendicitis. Lancet, ii, 227.

Reid, M.R., Poer, D.H. \& Merrell, P. (1936) A statistical study of 2921 cases of appendicitis. Journal of the American Medical Association, 106, 665.

ReNDle SHORT, A. (1920) The causation of appendicitis. British Journal of Surgery, 8, 171.

Rendle ShORT, A. (1946) The Causation of Appendicitis. Wright, Bristol.

Swanepoel, F.J. (1947) Personal communication. 
Treves, F. (1902) Perityphlitis. In: Allbutt's System of Medicine (Ed. by T. C. Allbutt), Vol. 3, p. 794. Macmillan, New York.

Trowell, H.C. (1960) Non-Infective Disease in Africa. Edward Arnold, London.

WALKER, A.R.P. (1947) The effect of recent changes of food habits on bowel motility. South African Medical Journal, 21, 590.

WALKer, A.R.P. (1961) Crude fibre, bowel motility, and pattern of diet. South African Medical Journal, 35, 114.

WALKER, A.R.P. (1964) Editorial. Coronary heart disease: limitations to the application to White populations of lessons learned from the underprivileged. Circulation, 29, 1.

W ALKER, A.R.P. (1966) Nutritional, biochemical and other studies on South African populations. South African Medical Journal, 40, 814.

WALKer, A.R.P. (1968) Coronary heart disease and future expectation of life. Circulation, 37, 126.
WAlker, A.R.P. (1970) Diet, bowel motility, faeces composition, and colonic cancer. South African Medical Journal, 45, 377.

WALKer, A.R.P. (1971) Sugar intake and coronary heart disease. Atherosclerosis, 14, 137.

WALKeR, A.R.P. \& WALkeR, B.F. (1969) Bowel motility and colonic cancer. British Medical Journal, 3, 238.

WALKER, A.R.P., HoldSWORTH, C.M.\& WALKER, E.J. (1971) Investigations on the consumption of sugar by South African populations. South African Medical Journal, 45, 516.

Wright, R.B. (1963) Invalidism from acute appendicitis. Lancet, ii, 475.

Young, M.\& RuSSEll, W.T. (1939) Appendicitis, a Statistical Study, Special Report Series, Medical Research Council, No. 2.33. H.M.S.O., London. 